\title{
ORGANIZACINĖS TYLOS VEIKSNIŲ RAIŠKA UGDYMO İSTAIGOSE
}

\author{
Greta BRUSOKAITE்*, Laima JESEVIČIŪTÉ-UFARTIENE் \\ Vilniaus Gedimino technikos universitetas, Verslo vadybos fakultetas, Vadybos katedra, \\ Sauletekio al. 11, 10223, Vilnius, Lietuva \\ *El.paštas greta.brusokaite@stud.vgtu.lt
}

\begin{abstract}
Santrauka. Organizacijos tobulinimas ir jos prisitaikymas prie kintančiu sąlygų konkurencingoje aplinkoje priklauso nuo darbuotojų galimybių laisvai pateikti savo žinias, norus, pasiūlymus ir iniciatyvas apie organizacijos pokyčius ir plëtrą. Jeigu darbuotojai neturi šių galimybių ar jaučiasi nepatogiai savo darbinèje aplinkoje, kyla grèsmé atsirasti organizacinei tylai. Šis reiškinys kuria neigiama pasekmes individualiai darbuotojui, tiek ir pačiai organizacijai bei jos teikiamų paslaugų kokybei, o tai, ypač, svarbu švietimo sektoriui, kadangi šias paslaugas gauna kiekvienas šalies pilietis. Tad šio straipsnio tikslas, remiantis moksliniais šaltiniais, ju analize bei empiriniu tyrimu, ištirti organizacinès tylos veiksniu pasireiškimą ugdymo ịstaigose. Tyrimui pasirinkta trys ugdymo ịstaigos (X1, X2, X3 - ístaigos norejo išlikti konfidencialios), kuriose buvo atlikta apklausa. Empirinio tyrimo duomenu analizei buvo taikytas daugiakriterinis TOPSIS metodas. Jis leido pastebẻti, kad organizacinès tylos veiksnių raiška trijose ugdymo ịstaigose yra skirtinga. Kadangi raiška kiekvienoje mokykloje skiriasi, galime daryti prielaidą, kad norint ištirti organizacinès tylos priežastis ir pasekmes reikia, kur kas platesnių tyrimų atskirai kiekvienai ugdymo įstaigai.
\end{abstract}

Reikšminiai žodžiai: organizacinè tyla, organizacinè kultūra, komunikacija, ugdymo ịstaigos, veiksnių raiška.

\section{Ivadas}

Šiandieniniame nuolat besikeičiančiame ir besivystančiame pasaulyje organizacijos galètu sèkmingai veikti, pristatyti naujus produktus, prisitaikyti prie naujų situacijų ir dèl to ilgainiui tęsti savo egzistavimą, didžiaja dalimi pasitelkdamos žmogiškajị faktorių. Šiuolaikinèse organizacijose darbdaviai stengiasi įtraukti darbuotojus ị įstaigos valdymą ir tikisi, kad jie išsakys savo idejjas, reaguos ị darbo aplinkos problemas ir aplinkos iššūkius, nebijos dalytis savo žiniomis, patirtimi bei gins savo organizacijos issitikinimus. Neretai darbuotojai turi idèjų, informacijos ir nuomonių, kaip konstruktyviai patobulinti darbą. Kartais šie darbuotojai išsako savo požiūrįi, o kitu metu jie tyli ir pasilaiko asmeninę nuomonę sau (Bagheri et al., 2012). Taigi reiškinys, kai organizacijos nariai atsisako pareikšti savo požiūri i organizacinius reikalus dèl ịvairių priežasčių, o toks reiškinys suprantamas kaip organizacine tyla (Chen, 2018).

Mokslininkai Tangirala ir Ramanujam (2008) pastebèjo, kad organizacinè tyla gali būti daugialypis reiškinys. Tai gali apimti skirtingas temas (pvz., darbo grupès efektyvumas ir produktyvumas, individualios problemos darbe, susirūpinimas etiškai netinkamu elgesiu), reiškinys gali būti taikomas skirtingiems veikejjams (pvz., darbuotojai, dirbantys specialistais, vidutinio lygio darbuotojai, vadovai, aukščiausio lygio vadovai) ir tai gali kilti dèl skirtingu tikslu ir priežasčiu (pvz., noras išsaugoti esamą situaciją, baimè būti nesuprastam) (Tangirala ir Ramanujam, 2008). Atsižvelgiant $i \mathfrak{t}$ tai, organizacinè tyla gali apimti skirtingų priežasčiu, sektorių, veikèjų, lygių, veiksnių derinius, o tai tik parodo, kad darbuotojų tylejjimas yra platus reiškinys, reikalaujantis didesnio mokslininkų dėmesio.

Organizacinès tylos reiškinys yra svarbus visoms organizacijoms. Ji yra tiriama tokiuose sektoriuose, kaip viešojo (Behtoui et al., 2017), sveikatos priežiūros (Yalçın ir Baykal, 2019), apgyvendinimo paslaugų (Zhang et al, 2018), finansų (Adeel ir Muhammad, 2017), ryšiu ir technologijų (Emelifeonwu ir Valk, 2019), sunkiosios pramonès (Dedahanov ir Rhee, 2015). Nagrinèjant mokslinę literatūrą tyrimų apie organizacinès tylos raišką švietimo sektoriuje pasigendama. Švietimo sistemos tikslas - išmokyti vaikus kūrybiškai ir kritiškai mąstyti, ieškoti atviru bei inovatyviu situacijos sprendimų (Valstybinè švietimo strategija 2013-2022 m.: tikslai, problemos, tobulinimo kryptys). Tam, kad pasiektume šio tikslo, patys mokytojai turi būti drąsūs, sumanūs, atviri naujovèms ir gebantys išsakyti savo nuomonę. Tad sąmoningas ugdytojų idejjų slëpimas gali turèti neigiamą poveikị mokyklų veiklai, raidai bei visai švietimo kokybei.

Tyrimo problema: kokie organizacinès tylos veiksniai pasireiškia ugdymo ịstaigose.

Tyrimo objektas: organizacinès tylos veiksniai.

Tyrimo tikslas: ištirti organizacinès tylos veiksnių pasireiškimą ugdymo įstaigose. 
Išsikelti uždaviniai tikslui pasiekti:

1. Apibrèžti organizacinès tylos sampratą;

2. Išskirti organizacinès tylos veiksnius;

3. Ivertinti organizacinès tylos veiksnius ugdymo įstaigose.

Darbo metodai: mokslinès literatūros analizè, daugiakriterinių duomenų analizè.

\section{Organizacinès tylos samprata}

Analizuojant organizacinės tylos sampratą svarbu atkreipti dėmesị, kad „tyla“ yra priešprieša sąvokai „balsas“ arba kitaip balso turejjimas organizacijoje. Pastaraisiais dešimtmečiais organizacijų vadyboje tokiai sąvokai, kaip „balsas“, buvo skiriama nemažai dėmesio (Allen, 2014). „Balso“ sąvoka apibūdinama, kaip žmogaus elgesio išraiška, kuria darbuotojas atskleidžia savo nuomonę, pasiūlymus ir idejjas. Tai tam tikras būdas, kuris palengvina darbuotojų dalyvavimą priimant sprendimus įmoneje (Emelifeonwu ir Valk, 2019). Siekiant efektyvios komunikacijos tarp organizacijos dalyvių, reikalingos dvi pusès: kalbančioji ir klausančioji. Tokiu būdu organizacijos komunikacijoje sąveikauja dvi komunikacijos formos: balsas ir tyla.

Balso ir tylos reiškinius organizacijoje pirmasis pristatė Hirschman (1970). Anot autoriaus, tyla organizacijoje buvo laikoma darbuotojų lojalumo ženklu. Darbuotojo tyla reikšdavo prielaidą, kad jis sutinka su savo kolegų ir viršininkų politika, sprendimais ir elgesiu - tai lyg tam tikras neveiklumas ir status quo patvirtinimas (Wynen et al., 2019). Toks tylos suvokimas buvo laikomas pozityviu darbuotojų požiūriu.

Visgi 1990-2000 m. pradžioje modernėjant visuomenei imta suprasti, kad yra svarbus darbuotojo požiūris i organizacijos vystymąsi ir pokyčius. Pasak autorių Köylüoğlu et al. (2015), informacijos generavimas nurunge klasikinị gamybos požiūrị ir dabartiniame globalizuotame pasaulyje reikia vis daugiau darbuotojų įsitraukimo i informacijos srautų suvaldymą organizacijos procesuose. Tad nuo XX a. dešimto dešimtmečio organizacinès tylos samprata suvokiama, kaip neigiamas veiksnys.

Taip pat pradèta manyti, kad tylejjimas organizacijose yra ne vien tik pasyvus pritariamo ženklas. Darbuotojų tyla gali būti aktyvi, sąmoninga, kryptinga, taip pat tyčinis arba netyčinis pasirinkimas. Tam turejo įtakos Morrison ir Milliken (2000), Pinder ir Harlos (2001) teorinès įžvalgos. Cohen (kaip cituota Pinder ir Harlos, 2001) tikriausiai pirmasis atmetė nuostatą, kad tyla būtinai reiškia pritarimą. Jis teigè, kad tyla gali reikšti ne tik prieštaravimus ir nesutarimus, bet taip pat gali kilti dèl informacijos trūkumo ar balso galimybių nebuvimo (Pinder ir Harlos, 2001). Tad tyla gali būti natūrali išraiška dèl tam tikrų aplinkybių. Ši netyčinị tylos pasireiškimą Penuel et al. (kaip cituota Le et al., 2019) pavadino „natūralia tyla“. Jo manymu, pati tylos esmès yra natūrali, kai organizacija neturi kito pasirinkimo, kaip tik tylèti.

Morrison ir Milliken (2000) organizacinę tylą apibrèžè, kaip kolektyvinį fenomeną. Jie patys pirmieji pavartojo sąvoką „organizacinè tyla“ ir sukūrè tylos klimato koncepciją, kad paaiškintų, kaip organizacijos kultūros normos daro ịtaką darbuotojų tylai (Wynen et al., 2019). Jie teigè, kad darbuotojai tyli, nes žino, kad išreikšti savo nuomonę bus beprasmiška ar pavojinga jų organizacijos kontekste. Tad darbuotojai yra ịtraukti ị tokị organizijos kultūros modelị, apimantị organizacijos politiką, demografines charakteristikas, aukščiausios vadovybės grupių įsitikinimus ir kolektyvo jausmų formavimą bei komunikacijos procesus. Šis modelis paaiškina, kaip žemesnio lygio darbuotojai tampa nusivylę arba bijo kalbèti. Taigi Morrison ir Milliken (2000) apibrèžè, kad kai darbuotojai nusprendžia nutylèti organizacinius dalykus, organizacinè tyla tampa kolektyviniu elgesiu.

Pinder ir Harlos (2001) išskiria kitokį sąmoningos organizacinès tylos supratimą, ją apibrezždami kaip asmens bet kokio pavidalo emocinès, pažintinès bei elgesio išraiškos sulaikymas, kai asmuo žino, kad tai gali turèti įtakos jam ar organizacijai. Pavydžiui, kai asmenys daro tai, ko iš jų tikimasi ir neišsako savo minčių, tai gali būti vienas iš protesto ženklų organizacijoje (Dedahanov ir Rhee, 2015). Tad darbuotojų tylejimo reiškinys gali igyti skirtingas reikšmes atsižvelgiant i jo pagrindinius motyvus. Darbuotojai savo valia turédami individualių motyvų gali pasirinkti neatskleisti savo nuomonès. Motyvai, dèl kurių asmuo tyli, gali būti ịvairūs. Pavyzdžiui, Mokhtari (2016) išskyrè šiuos:

- vadybiniai veiksniai (neigiama vadovo reakcija i komentarus, prievartinis vadovavimo stilius, darbuotojų baimè dèl neigiamų atsiliepimų i jų komentarus, nepasitikèjimo ir ịtarimo atmosfera),

- organizaciniai veiksniai (darbo inercija, centralizuota organizacinè struktūra ir aukštyn kylančios grị̌žtamojo ryšio procedūros nebuvimas),

- socialiniai veiksniai (atitikimas kitiems, grupinès atsakomybès egzistavimas vietoje asmeninès atsakomybès ir grupinio mąstymo) ir

- asmeniniai veiksniai (esamos situacijos išsaugojimas ir vadovo pesimizmas) (Bordbar et al., 2019).

Taigi darbuotojų tyla gali kilti ne tik dẻl pačios organizacijos modelio, bet ir dèl asmeninių interesų.

Kalbant apie organizacinès tylos atsiradimo priežastis, jų gali būti ịvairių. 1 paveiksle pavaizduota modelis, kuriame atskleista dažniausios tylèjimo priežastys ir pasekmès organizacinès tylos kilimui (Milliken et al., 2003). Pavyzdžiui, darbuotojas, kuris turi mažai patirties, tiki, kad jo nuomonè yra bereikšmè ir nieko nepakeis, tokiu atveju darbuotojas dažniausiai renkasi tylèti. Visgi šis tylëjimas vèliau gali turèti pasekmių darbuotojo psichologinei būsenai ir visai organizacijai. Darbuotojai tylą gali rinktis ne tik dẻl žemos savivertès, bet ir dèl informacijos 
trūkumo, baimès, asmenybės savybių, neigiamų patirčių. Tad įvairūs mokslininkai, tokie kaip Morrison ir Milliken (2000), Pinder ir Harlos (2001), Dyne et al. (2003), organizacinès tylos reiškinio apibrěžimą ir priežastis įvardija skirtingai.

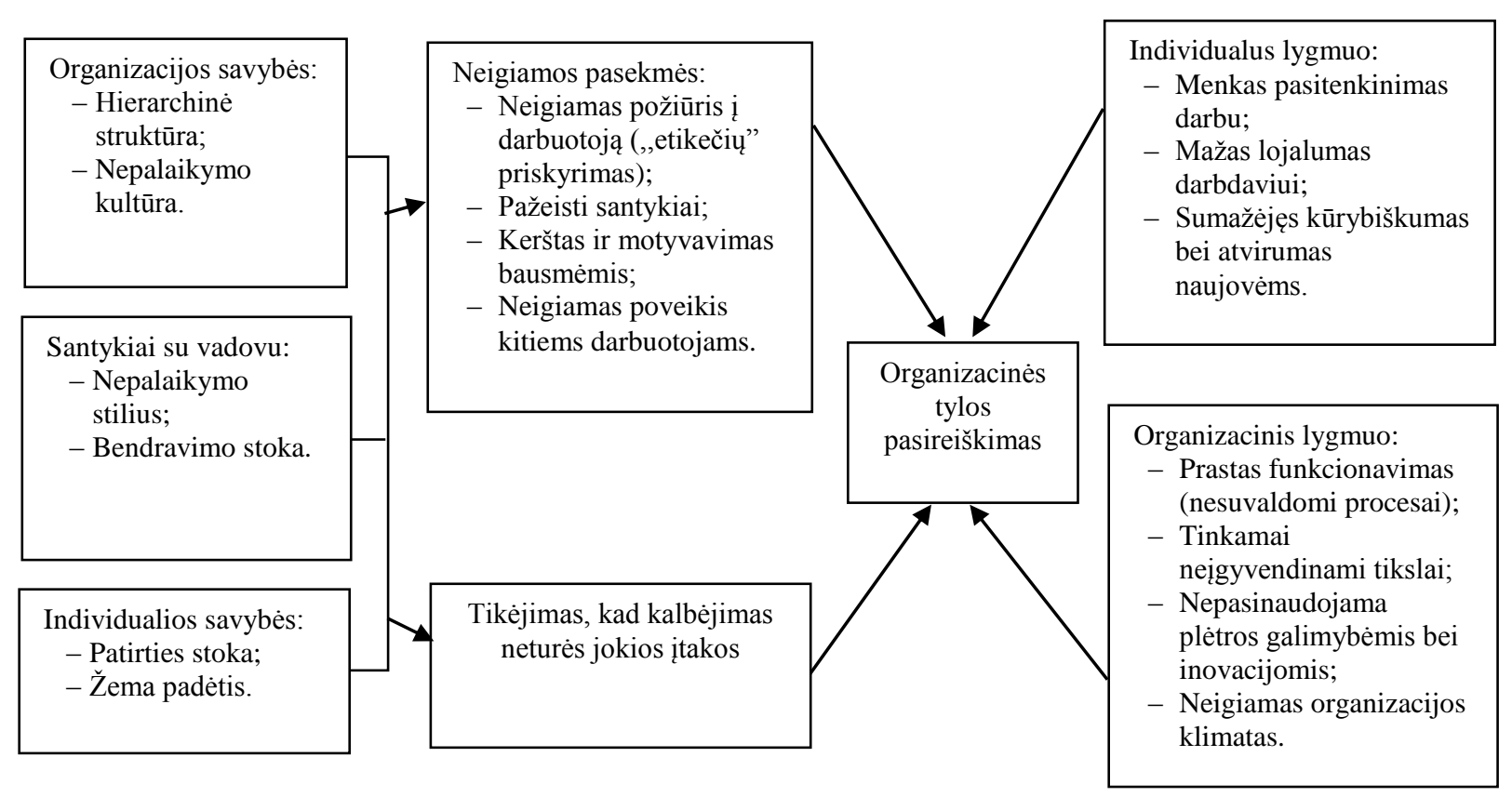

1 paveikslas. Pasirinkimo tylèti modelis (šaltinis: sudaryta autorių remiantis Milliken et al. (2003)

Dar vienas svarbus aspektas nagrinejjant organizacinės tylos sampratą yra šio reiškinio poveikis organizacijai ir kiekvienam darbuotojui individualiai. 1 paveiksle pavaizduota dẻl ko gali kilti organizacinè tyla, tačiau šią schema galima būtų pratęsti, nes po tylos reiškinio buvimo gali kilti dar didesnès neigiamos pasekmès. Kalbėdami apie ugdymo įstaigas, žmogiškieji ištekliai yra svarbiausias įstaigų darbo komponentas, kadangi būtent tai kuria vertę ateities kartoms. Tad yra labai svarbu žinoti ir suprasti darbuotojo požiūrị ị darbą bei motyvaciją dalyvaujant ugdymo įstaigos procesuose. Kai darbuotojų tyla virsta ịsišaknijusiu ịsitikinimu, jie pradedami laikyti beverčiais įstaigos nariais. Tuomet atsiranda psichologiniai prieštaravimai tarp to, ką žmogus daro ir ką galvoja. Tokia situacija neigiamai veikia darbuotojų pasitenkinimą darbu, lojalumą ir motyvaciją (Akar, 2018), o būtent tai trukdo darbuotojui būti kūrybišku bei atviru naujovèms ugdymo įstaigoje.

Be to, yra manoma, kad bendravimas yra raktas ị organizacijos sẻkmę. Jeigu darbuotojai remiasi tyla, kenčia bendravimas ir bendras ugdymo įstaigos funkcionavimas (Bagheri et al., 2012). Teigiamas ir neigiamas santykis tarp darbuotojų yra, ypač, jaučiamas ugdymo ịstaigose, kadangi jiems kiekvieną dieną tenka keistis informacija ar idejomis. Neesant bendradarbiavimui tokiose įstaigose sunku užtikrinti reikiamus informacijos srautus bei pasiekti organizacinius tiklus (Köse ir Köse, 2019). Taip pat yra stabdomas klaidų, problemų paaiškejjimas ir iškreipiamas veiksmingų sprendimų prièmimas vien dẻl to, kad darbuotojai neišsako savo nuomonès. Taigi organizacinè tyla išryškejja kaip neefektyvus procesas, eikvojantis energiją ir pastangas.

Kai kuriais atvejais darbuotojų tylèjimas gali būti naudingas, nes tai gali padèti sumažinti vadybinès informacijos perteklių, tarpasmeninius konfliktus ir padidinti bendradarbių informacijos privatumą (Tangirala ir Ramanujam, 2008). Visgi organizacinè tyla dažniau vertinama kaip žalingas fenomenas. Be to, nepaisant to, kad organizacinè tyla yra naujas fenomenas turintis didelę komunikacinę reikšmę bei pasekmes tiek individualiu, tiek organizaciniu lygiu. Pagrindinès priežastys ir teorijos rodo, kad organizacinè tyla yra svarbi ir šiuolaikiška organizacijų problema (Köse ir Köse, 2019). Tai atveria kelią faktui, kad reikia ieškoti ir išsamiau išnagrinèti organizacinę tylą kiekvienoje atskiroje ugdymo įstaigoje.

\section{Organizacinès tylos veiksniai}

Organizacinė tyla gali vykti įvairiomis formomis, tokiomis kaip tylejjimas susirinkimuose, žemas dalyvavimo pasiūlymų teikimo lygis, žemas kolektyvinio balso lygis ir pan. (Bagheri et al., 2012). Visgi, kad gebėtume atpažinti darbuotojų tylą, reikia žinoti ne tik pasireiškimo formas, bet ir tylos veiksnius.

Pirmiausia, yra daugybè veiksnių, kuriais remiantis yra nagrinejjama organizacinė tyla įstaigose. Išnagrinejjus literatūrą daugiausia yra minimi šie tylos veiksniai: paklusni (angl. Acquiescent Silence) (Pinder ir Harlos, 2001) 
gynybinè (angl. Defensive Silence) (Pinder ir Harlos, 2001) ir prosociali tyla (angl. Prosocial silence) (Dyne et al., 2003).

Paklusnios ir gynybinès tylos veiksnius pirmieji paminèjo Pinder ir Harlos (2001) (Amiri et al., 2018). Paklusni_tyla - tai pasyvaus elgesio forma (Nafei, 2016). Taikydami šią formą darbuotojai pasižymi mažu dalyvavimu, aplaidumu ir neveiklumu. Tokie darbuotojai, nors ir turi svarbių nuomonių ar idejjų, stengiasi atsiriboti nuo susiklosčiusios situacijos ir nenori įsitraukti ar bandyti pakeisti situaciją, nes mano, kad jų nuomonè nepadarys jokio poveikio. Šią tylos formą yra ypač sunku sutrikdyti (Pinder ir Harlos, 2001). Autoriai Dedahanov ir Rhee (2015) pateikia paklusnios tylos pavyzdį: kai vadovai nereaguoja ị pateiktą informaciją iš darbuotojų arba vadovybė neskantina darbuotojų dalyvauti aptariant organizacinius klausimus, darbuotojai supranta, kad kalbėti yra nenaudinga ir dèl to nieko nekeičia, remdamiesi tokiu suvokimu, jie tampa tylūs. Tad šioje situacijoje galime ižvelgti, kad tai yra tyčinis pasyvus elgesys, kuomet darbuotojas neteikia reikiamos informacijos ir tiesiog pasitenkina esama situacija.

Kitaip nei paklusni tyla, gynybinè - tai aktyvus darbuotojų elgesys (Wynen et al., 2019). Šios formos tyla parodo, kad asmuo nusprendžia, jog kalbėjimas yra rizikingas jo pozicijai, nes tai gali sukelti ginčus, prieštaravimus arba sankcijas, ir kad ši rizika nusveria kalbejjimo pranašumus. Darbuotojai savo iniciatyva sąmoningai naudojasi šia tyla norèdami ,apsiginti““ nuo pašalinių elgesio ir siekdami apsaugoti savo esamą padètị (Bordbar et al., 2019). Tad pagrindinis gynybinès tylos motyvas yra baimè dẻl galimų kiekvienam individualiai nepalankių pasekmių.

Autoriai Dyne et al. (2003) pripažino, kad tyla gali būti ne tik pasyvus elgesys ar grịstas baime, bet ir kryptingai, tikslingai ir sąmoningai apgalvotas elgesys. Tai yra svarbus punktas, nes atskleidžia sudètingą ir daugialypị tylos pobūdị (Amiri et al., 2018). İvertinus ši punktą autoriai Dyne et al. (2003) pateiké dar vieną organizacinès tylos veiksni - prosocialią tylą. Prosociali tyla - tai su darboviete susiejusių idejų, informacijos ar nuomonių atsisakymas atskleisti remiantis altruizmu ir bendradarbiavimo motyvais (Dyne et al., 2003). Manoma, kad prosociali tyla yra organizacinio pilietiškumo padarinys, kadangi darbuotojai sąmoningai ir tikslingai siekia suteikti naudos kolegoms ir darbovietei nelaukdami atlygio (Shahjehan ir Yasir, 2016). Taigi galima manyti, kad prosociali tyla yra nežalinga organizacijai.

Nors yra išskiriami trys organizacinès tylos veiksniai: paklusni, gynybinè ir prosociali tyla, autoriai Pinder ir Harlos (2001) teigia, kad įvairūs organizacinès tylos veiksniai ar formos gali turèti keletą reikšmių, atsižvelgiant ị konktekstą, kuriame jos pasireiškia. Tad norint apibrěžti raišką tam tikroje ugdymo įstaigoje, reikia kur kas didesnių empirinių tyrimų.

\section{Tyrimas ir jo rezultatai}

Tyrime yra nagrinejjama trijų organizacinès tylos veiknių (paklusni, gynybinè, prosociali tyla) raiška trijose ugdymo įstaigose 2019 metų spalio mėnesį. Kiekvienoje mokykloje spalio ménesio viduryje buvo gauti leidimai atlikti tyrimą, tačiau ugdymo ịstaigos norejo, jog rezultatai išliktų konfidencialūs. Tad mokyklos dalyvavusios tyrime buvo užtikrintos, kad jų duomenys bei atsakymai nebus paviešinti. Šiame darbe įstaigos užkoduotos ir toliau tyrime bus atpažįstamos, kaip $\mathrm{X}_{1}, \mathrm{X}_{2}, \mathrm{X}_{3}$. Tyrimui pasirinkta apklausti mokytojus, kadangi ugdymo ịstaigose mokytojai sudaro didžiają personalo dalį. Be to, kaip jau minèta, mokytojai yra švietimo paslaugų teikejjai, tad organizacinès tylos pasireiškimas gali turèti pasekmių ne tik indivudaliai mokytojams, bet ir visam švietimo sektoriaus skaidrumui ir paslaugų kokybei. Toliau 1 lentelè. Tyrimo imtis (sudaryta autorių) 1 lentelèje matomas apklaustujų skaičius.

1 lentelè. Apklaustujų skaičius

\begin{tabular}{|c|c|c|c|c|}
\hline & $\begin{array}{c}\text { Iš viso dirbančių mokytojų } \\
\text { ugdymo ịstaigoje }\end{array}$ & $\begin{array}{c}\text { Būtinoji tyrimo } \\
\text { imtis }\end{array}$ & $\begin{array}{c}\text { Apklaustujų skaičius procentine } \\
\text { išraiška (\%) }\end{array}$ & $\begin{array}{c}\text { Apklaustujų } \\
\text { skaičius }\end{array}$ \\
\hline $\mathrm{X}_{1}$ & 35 & 33 & 94,3 & 33 \\
\hline $\mathrm{X}_{2}$ & 36 & 33 & 91,7 & 33 \\
\hline $\mathrm{X}_{3}$ & 40 & 37 & 92,5 & 37 \\
\hline
\end{tabular}

Tiriamujų atrankos būdas - atsitiktinès atranka. Atsitiktinai buvo prašoma visų kiekvienos ugdymo įstaigos mokytojų dalyvauti apklausoje. Visgi norint gauti tikslesnius duomenis, kuriuos būtų galima naudoti tyrime, buvo vertinta tyrimo duomenų patikimumas bei jų tikslumas, t. y. tikrinama imties reprezentatyvumas remiantis „Raosoft“" skaičiuokle (Raosoft, 2004). Tyrimo imties pagrindimą matome 1 lentelès penktame stulpelyje. Per tris mokyklas buvo gauta 103 respondentų atsakymai. $\mathrm{X}_{1}$ mokykloje iš 35 dirbančių asmenų apklausta 33 respondentai, $\mathrm{X}_{2}$ istaigoje iš 36 apklausta taip pat 33 respondentas, o $\mathrm{X}_{3}$ ugdymo įstaigoje apklausta 37 iš 40 asmenų. Taigi taikant $5 \%$ paklaidą, duomenys buvo surinkti standartiniu $95 \%$ patikimumu.

Kiekybinam tyrimui gauti mokytojams buvo naudojamas apklausos metodas. Apklausa buvo vykdoma pateikus anoniminę anketą per internetą. Klausimynas anketai sudarytas remiantis mokslininkų Dyne et al. (2003) 
matavimo skale. Klausimai išversti ir adaptuoti tik šiam tyrimui. Kiekvienam organizacinès tylos veiksniui buvo priskirta po penkis klausimus/kriterijus atskleidžiančius jų pobūdị. Tyrimo gautiems rezultatams analizuoti naudojamas daugiakriterinis metodas TOPSIS. Šio metodo tikslas - suranguoti ugdymo ịstaigas pagal organizacinės tylos veiksnius. Norint parodyti veiksnių raišką buvo išsikelta tyrimo hipotezė:

Hipoteze: kiekvienoje ugdymo įstaigoje organizacinès tylos raiška yra skirtinga.

Toliau kiekvieno klausimo/kriterijaus atsakymams atskiroms mokykloms buvo išvestas vidurkis. 2 lentelejje matome gautus atsakymų vidurkius suvestus ị matricos lentelę, t. y. pirminiai duomenys.

2 lentelè. Pirminiai duomenys (sudaryta autorių)

\begin{tabular}{|c|c|c|c|c|}
\hline $\begin{array}{c}\text { Organizacinès } \\
\text { tylos } \\
\text { veiksniai }\end{array}$ & Tyrimo teiginiai & $\mathrm{X} 1$ & $\mathrm{X} 2$ & $\mathrm{X} 3$ \\
\hline \multirow{5}{*}{ Paklusni tyla } & $\begin{array}{l}\text { Aš neteikiu savo pasiūlymų apie galimus pakeitimus, nes jaučiuosi } \\
\text { atskirtas nuo kolektyvo. }\end{array}$ & 1,85 & 1,84 & 1,87 \\
\hline & Aš nuslepiu savo idèjas, nes planuoju išeiti iš darbo. & 1,42 & 1,48 & 1,77 \\
\hline & Aš pasilaikau idèjas apie galimus problemos sprendimus sau. & 2,00 & 1,90 & 2,59 \\
\hline & $\begin{array}{l}\text { Aš pasilaikau idèjas apie galimus tobulinimus sau, nes netikiu, kad tos } \\
\text { idejos bus naudingos. }\end{array}$ & 2,03 & 2,13 & 2,79 \\
\hline & $\begin{array}{l}\text { Aš pasilaikau idejjas apie galimus tobulinimus sau, nes nenoriu būti } \\
\text { atskirtas. }\end{array}$ & 1,94 & 1,87 & 1,85 \\
\hline \multirow{5}{*}{ Gynybinè tyla } & Aš tyliai pasilaikau galimų pakeitimų idèjas, nes bijau. & 1,85 & 1,58 & 2,10 \\
\hline & Aš nesidalinu aktualia informacija, nes bijau. & 1,61 & 1,61 & 2,00 \\
\hline & Aš nutyliu apie svarbius faktus, nes tokiu būdu save saugau. & 2,03 & 1,87 & 2,33 \\
\hline & Aš vengiu išsakyti idèjas apie galimus tobulinimus, nes saugau save. & 1,88 & 1,81 & 2,18 \\
\hline & $\begin{array}{l}\text { Aš nutyliu problemų sprendimus, nes darbe esu motyvuojamas } \\
\text { bausmėmis. }\end{array}$ & 1,48 & 1,52 & 1,22 \\
\hline \multirow{5}{*}{$\begin{array}{l}\text { Prosociali } \\
\text { tyla }\end{array}$} & Aš nutyliu konfidencialią informaciją, nes toks yra susitarimas. & 3,64 & 3,52 & 3,59 \\
\hline & $\begin{array}{l}\text { Aš saugau darbovietès vidinę informaciją, siekdamas naudos } \\
\text { darbdaviui. }\end{array}$ & 3,21 & 3,10 & 3,59 \\
\hline & Aš išlaikau darbdavio paslaptis, nors patiriu spaudimą iš kitų. & 2,61 & 2,71 & 3,00 \\
\hline & Aš atsisakau atskleisti informaciją, kuri gali pakenkti darbovietei. & 3,76 & 3,65 & 3,79 \\
\hline & $\begin{array}{l}\text { Aš tinkamai saugau darbovietės konfidencialią informaciją, nes man } \\
\text { rūpi darbdavys. }\end{array}$ & 3,79 & 3,61 & 3,33 \\
\hline
\end{tabular}

Kadangi kriterijai yra vienodai svarbūs vertinant organizacinès tylos veiksnius įstaigose, kriterijų svoriai imti vienodi, t. y. po 0,2 (3 lentelè), bei kriterijų veiksniai visur yra maksimizuojantys.

3 lentelè. Turimi duomenys (svoriai ir tipai) (sudaryta autorių)

\begin{tabular}{|c|c|c|c|c|c|}
\hline Svoris & 0,2 & 0,2 & 0,2 & 0,2 & 0,2 \\
\hline Kriterijaus tipas & $\max$ & $\max$ & $\max$ & $\max$ & $\max$ \\
\hline
\end{tabular}

Pirmiausia, visų lentelių duomenys buvo normalizuojami remiantis normalizavimo (1) formule:

$$
n_{i j}=\frac{x_{i j}}{\sqrt{\sum_{i=1}^{m} x_{i j}^{2}}}
$$

čia: $n_{i j}$ - normalizuotasis j-ojo objekto i-tojo kriterijaus reikšmės; $x_{i j}$ - esama reikšmė; $\sum_{i=1}^{m} x i j^{2}-$ esamų reikšmių kvadratų suma.

Sekančiame žingsnyje apskaičiuota svertinè matrica pagal (2) formulę:

$$
v_{i j}=w_{j} n_{i j}
$$

čia: $w_{j}$ - j-tojo kriterijau svoris; $n_{i j}$ - normalizuotasis j-ojo objekto i-tojo kriterijaus reikšmès. 
Toliau nustatyti idealusis teigiamas sprendimas (žr. (3) formulę):

$$
V^{+}=\left(v_{1}^{+}, v_{2}^{+}, \ldots, v_{n}^{+}\right)=\left(\left(\max _{i} v_{i j} \mid j \in I\right),\left(\min _{i} v_{i j} \mid j \in J\right)\right) .
$$

Ir idealus neigiamas sprendimas (̌̌r. (4) formulę):

$$
V^{-}=\left(v_{1}^{-}, v_{2}^{-}, \ldots, v_{n}^{-}\right)=\left(\left(\min _{i} v_{i j} \mid j \in I\right),\left(\max _{i} v_{i j} \mid j \in J\right)\right) .
$$

Tuomet apskaičiuotas atstumas iki idealaus teigiamo sprendimo (žr. (5) formulę):

$$
S_{i}^{+}=\sqrt{\sum_{j=1}^{n}}\left(v_{i j}-v_{i}^{+}\right)^{2}, \mathrm{i}=1,2, . ., \mathrm{m} .
$$

Ir idealus neigiamas sprendimas pagal (6) formulę:

$$
S_{i}^{-}=\sqrt{\sum_{j=1}^{n}}\left(v_{i j}-v_{i}^{-}\right)^{2}, \mathrm{i}=1,2, \ldots, \mathrm{m},
$$

čia: $S^{+}{ }_{i}$ - atstumas iki idealaus teigiamo sprendimo; $S_{i}-$ atstumas iki idealaus neigiamo sprendimo; $v_{i j}-$ esama reikšmé; $V_{i}^{+}$-idealus teigiamas sprendimas; $V_{i}-$ idealus neigiamas sprendimas.

Galiausiai, taikoma (7) formulè apskaičiuoti santykini atstumą teigiamam idealiam sprendimui ir suranguojami gauti atsakymai:

$$
P_{i}=\frac{S_{i}^{-}}{S_{i}^{-}+S_{i}^{+}}
$$

čia: $S^{+}{ }_{i}$ - atstumas iki idealaus teigiamo sprendimo; $S_{i}{ }_{i}$ atstumas iki idealaus neigiamo sprendimo; $P_{i}-$ santykinis artumas teigiamam idealiam sprendimui.

4 lentelè. Santykinis artumas teigiamam idealiam sprendimui ir rangai

\begin{tabular}{|c|c|c|c|}
\hline & $\left(P_{i}\right)$ Rank-paklusni tyla & $\left(P_{i}\right)$ Rank-gynybine tyla & $\left(P_{i}\right)$ Rank-prosociali tyla \\
\hline $\mathrm{X}_{1}$ & $(1,0551) 1$ & $(1,0391) 2$ & $(1,0211) 2$ \\
\hline $\mathrm{X}_{2}$ & $(1,0535) 2$ & $(1,0533) 1$ & $(1,0226) 1$ \\
\hline $\mathrm{X}_{3}$ & $(1,0057) 3$ & $(1,0146) 3$ & $(1,0147) 3$ \\
\hline
\end{tabular}

Pritaikius TOPSIS metodą turimiems duomenimis buvo gauti rezultatai, kurie atsispindi 4 lentelëje. Surangavus mokyklas pagal veiksnius, galime pastebėti, kad gynybinė ir prosociali tyla ugdymo įstaigose pasireiškia gana panašiai. $X_{2}$ ugdymo įstaigoje šie veiksniai pasireiškia labiausiai, tuomet $X_{1}$ ịstaigoje šiek tiek mažiau, o $X_{3}$ mažiausiai, kadangi pagal rangą liko trečioje vietoje. Paklusnios tylos veiksnio raiškos rangai pasiskirstė visiškai kitaip. Pirmoje vietoje atsidūre $\mathrm{X}_{1}$ ugdymo įstaiga, antroje $-\mathrm{X}_{2,}$ o trečioje vietoje paskutine $\mathrm{X}_{3}$ mokykla.

Pavaizdavus visus gautus rezultatus grafiškai 2 paveiksle galima pastebèti, kad ugdymo įstaigose didžiausia raiška yra paklusnios ir gynybinès tylos veiksnių, kadangi jų stulpeliai yra aukščiausi. Nors išnagrinèjus mokslinę literatūrą prosociali tyla yra nežalinga, šis veiksnys pasireiškia kur kas mažiau ugdymo ịstaigose. Taip pat tiek 4 lenteleje, tiek 2 paveiksle matome, $\mathrm{kad}_{3}$ ugdymo įstaiga surangavus duomenis pagal veiksnius visur yra trečioje vietoje, tad galima daryti prielaidą, kad šioje įstaigoje organizacinès tylos reiškinys pasižymi mažiausiu lygiu.

Taigi 2 paveiksle stulpeliai visi išsidèstę netolygiai, raiška visose ugdymo ịstaigose skiriasi. Tad tyrimo hipotezè pasitvirtino. Kaip ir minèta, tam gali turèti įtakos skirtingi mechanizmai: vadovo vaidmuo įstaigoje, mikroklimatas, profesinis įsipareigojimas ar individualūs motyvai (Tangirala ir Ramanujam, 2008). Taigi norèdami mažinti organizacinès tylos veiksnių raišką, reikia kur kas didesnių empirinių tyrimų, kurie pateiktų raiškos priežastis, ryšius bei atsiradusias neigiamas pasekmes kiekvienoje atskiroje ugdymo įstaigoje.

Atsižvelgiant ị tai, jog organizacinės tylos efektas yra žalingas kiekvienai ugdymo ịstaigai, yra manoma, jog reikia imtis tam tikrų priemonių dar prieš pasireiškiant tylai. İstaigos pakeitimas iš tokios, kuriai būdinga tylos atmosfera, i tokią, kuri skatina darbuotoų aktyvumą, gali pareikalauti revoliucinių sistemos pakeitimų. Visgi mokslinès literatūros šaltiniuose teigiama, kad viso to pradžia turi būti ịstaigu vadovai (Bagheri et al., 2012). Yra nustatyta, kad tarp pasitikejjimo vadovu ir paklusnios bei gynybinès tylos veiksnių yra neigiama korealiacija. Tai reiškia, kad didejjant pasitikejjimui, organizacinès tylos veiksniai mažėja ir atvirkščiai (Dedahanov ir Rhee, 2015). 
Kai darbuotojai mano, kad vadovai neturi gerų ketinimų jiems, nesielgia su jais tinkamai ir tik demotyvuoja, tokiu atveju darbuotojai yra nelinkę dalytis informacija. Dèl šios priežasties, vadovai turi suvokti organizacinės tylos pasekmes ir imtis priemonių, kurios užkirstų kelią organizacinès tylos raiškai.

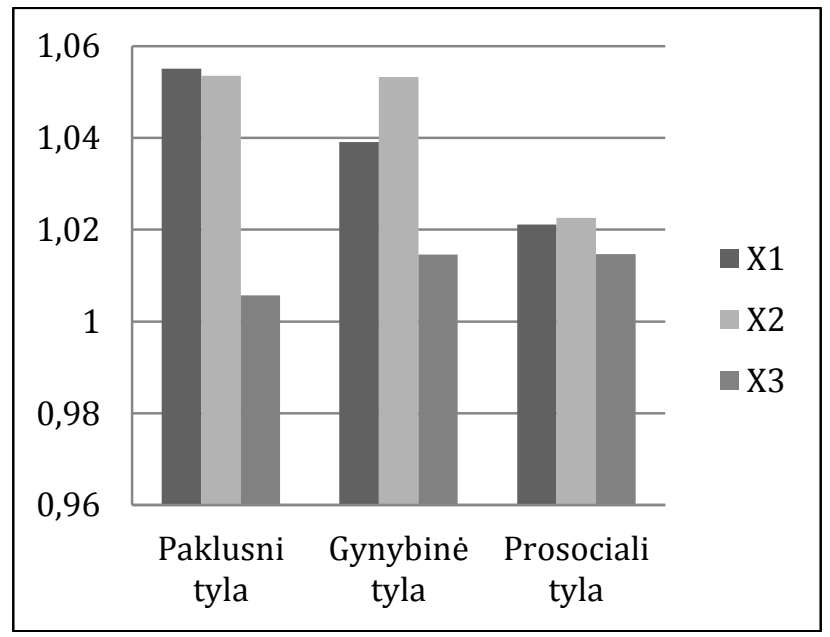

2 paveikslas. Organizacinès tylos veiksnių raiška ugdymo įstaigose (šaltinis: sudaryta autorių)

Viena iš prevencinių priemonių trukdančių plèstis organizacinès tylos veiksniams yra darbuotojų atsakomybių didinimas. Darbuotojų įsipareigojimų turèjimas organizacijai taip pat neigiamai koreliuoja su organizacine tyla (Qazelvand ir Shahtalebi, 2016). Vadovai deleguodami atsakingus darbus kitiems darbuotojams, tokiu būdu išreiškia savo pasitikèjimą bei stiprina darbuotojų tapatumą ir emocini prisirišimą prie organizacijos (Hassan et al., 2019). Darbuotojų įtraukimas ị valdymą kuria tam tikrą santykị ir komunikaciją su vadovais, tuo pačiu atsiranda saugi atmosfera, kuri skatina žmones jausti bendrumą ir laisvę pasisakyti (Bagheri et al., 2012). Tad daugiau atsakomybių suteikia darbuotojui žinojimą, kad jo indèlis ị organizaciją yra vertinamas ir kad nuomonès ir idèjų išsakymas tik padeda organizacijai stiprèti ir plèstis.

Taigi be atsakomybių ir ịsipareigojimų suteikimo darbuotojams, mokslinèje literatūroje yra minimos dar kelios priemonès, tai žmogiškuju išteklių valdymo sistemų įdiegimas įstaigose bei bendradvimo igūdžių lavinimo seminarai vadovams ir darbuotojams (Amiri et al., 2018). Visgi visos prevencinès priemonès norint užkirsti ar sumažinti organizacinès tylos pasireiškimą, turi kilti iš vadovaujančias pocizijas užimančių asmenų. Jie turi suprasti bei parodyti norą keisti darbuotojų elgesį, skatinti atvirumą bei grị̌tamajji ryši. Tinkamiausioms prevencinėms priemonėms ugdymo įstaigose organizacinès tylos reiškiniui valdyti galètų būti identifikuotos atliekant papildomus tyrimus.

\section{Išvados}

1. Darbuotojų tyla reiškia ne vien tik kalbos trūkumą, bet ir nekalbèjimą, kai yra pasiūlymas, susirūpinimas, informacija apie problemas bei skirtinga nuomoné, kuri gali būti naudinga organizacijos kontekste. Toks darbuotojų tylëjimas yra vadinamas organizacine tyla. Šis reiškinys yra vienas iš barjerų i organizacijos sẻkmę. Sunkiausia yra atsakyti, kodẻl darbuotojai tyli, kadangi tam daro įtaką daugybė faktorių, tokių kaip sprendimų prièmimo procesai, valdymo procesai, kultūra ir darbuotojų suvokimas apie veiksnius, turinčius ịtakos tylos elgesiui. Tad jie gali būti asmeniniai tiek kylantys iš pačios organizacijos. Organizacinès tylos pasekmės gali pasireiškti taip pat tiek individualiu, tiek organizaciniu lygmeniu. Darbuotojų tyla sukelia psichologines problemas bei trukdo pasiekti organizacinius tikslus ar ịžvelgti galimybes pokyčiams bei plètrai organizacijoje. Taigi organizacinė tyla yra svarbi kiekvienai ịstaigai, o ypač, ugdymo ịstaigoms, kadangi dèl to gali nukentèti švietimo kokybè.

2. Organizacinè tyla yra skirstoma ị tris veiksnius: paklusnią (angl. Acquiescent Silence) ir gynybinę (angl. Defensive Silence) ir prosocialią tylą (angl. Prosocial Silence). Be to, mokslininkai teigia, kad ìvairios organizacinès tylos formos ar kategorijos gali turèti keletą reikšmių, atsižvelgiant ị konktekstą, kuriame jos pasireiškia.

3. Organizacinès tylos veiksnių raiška ugdymo įstaigose yra skirtinga. Kadangi pritaikius duomenims diaugiakriterini metodą organizacinès tylos veiksnių rangai pasiskirstė nevienodai. Paklusnios tylos veiksnio rangai išsidèste iš eilès pagal mokyklas, $t$. $y$. pirmoje vietoje $X_{1}$, antroje $-X_{2}$ ugdymo ịstaiga ir $\mathrm{X}_{3}$ - trečioje vietoje. Gynybinès ir prosocialios tylos rangų pasiskirstymas pagal gautus rezultatus vienodas, t. $y$. pirmoje vietoje $X_{2}$ ugdymo ịstaiga, antroje $-X_{1}$, o trečioje vietoje $X_{3}$ mokykla. Visgi 
pavaizdavus duomenis grafiškai, nors ugdymo įstaigų rangai išlieka tie patys, bet rezultatų išsidėstymas visiškai skiriasi. Taigi norèdami sužinoti tikslesnius organizacinės tylos veiksnių raiškos mastus, reikia kur kas didesnių empirinių tyrimų, kurie pateiktų raiškos priežastis, ryšius bei atsiradusias neigiamas pasekmes kiekvienoje atskiroje ugdymo įstaigoje.

\section{Literatūra}

Adeel, S., \& Muhammad, A. (2017). Employee silence as mediator in the relationship between toxic leadership behavior and organizational learning. Abasyn Journal of Social Sciences, 10(2), 294-310.

Akar, H. (2018). Organizational silence in educational organizations: A meta-analysis study. International Journal of Eurasia Social Sciences, 9(32), 1077-1098.

Allen, M. M. C. (2014). Hirschman and voice. In A. Wilkinson, J. Donaghey, T. Dundon, \& R. B. Freeman (Eds.), Handbook of research on employee voice (chapter 3, pp. 36-51). https://doi.org/10.4337/9780857939272.00010

Amiri, A., Zare kahnali, M., Alamdari, A., \& Nejad, R. (2018). Investigating the relationship between silence and organizational commitment (Case study: Shiraz University of Medical Sciences). Revista Publicando, 5(15-2), 893906.

Bagheri, G., Zarei, R., \& Aeen, M. N. (2012). Organizational silence (basic concepts and its development factors). Ideal Type of Management, 1(1), 47-58.

https://www.researchgate.net/profile/Mojtaba_Nikaeen/publication/259383988_Organizational_Silence_Basic_Concept s_and_Its_Development_Factors/links/00463530707dcd184d000000.pdf

Behtoui, A., Boréus, K., Neergaard, A., \& Yazdanpanah, S. (2017). Speaking up, leaving or keeping silent: Racialized employees in the Swedish elderly care sector. Work, Employment and Society, 31(6), 954-971. https://doi.org/10.1177/0950017016667042

Bordbar, G., Shad, F. S., Rahimi, E., \& Rostami, N. A. (2019). Effect of organizational silence on employees' productivity. International Journal of Management, Accounting and Economics, 6(3), 198-207.

Chen, Y. (2018). Can Supervisor support mitigate the impact of colleague exclusion on silence behavior? - A moderated mediating model. Open Journal of Social Sciences, 6(10), 132-145. https://doi.org/10.4236/jss.2018.610011

Dedahanov, A. T., \& Rhee, J. (2015). Examining the relationships among trust, silence and organizational commitment. Management Decision, 53(8), 1843-1857. https://doi.org/10.1108/MD-02-2015-0041

Dyne, L. Van, Ang, S., \& Botero, I. C. (2003). Conceptualizing employee silence and employee voice as multidimensional constructs. Journal of Management Studies, 40(6), 1359-1392. https://doi.org/10.1111/1467-6486.00384

Emelifeonwu, J. C., \& Valk, R. (2019). Employee voice and silence in multinational corporations in the mobile telecommunications industry in Nigeria. Employee Relations, 41(1), 228-252. https://doi.org/10.1108/ER-04-2017-0073

Hassan, S., DeHart-Davis, L., \& Jiang, Z. (2019). How empowering leadership reduces employee silence in public organizations. Public Administration, 97(1), 116-131. https://doi.org/10.1111/padm.12571

Hirschman, A. O. (1970). Exit, voice, and loyalty: Responses to decline in firms, organizations, and states. Cambridge, MA: Harvard University Press.

Köse, A., \& Köse, F. (2019). An analysis of teachers' perception of organizational silence in terms of various demographic variables. Universal Journal of Educational Research, 7(2), 307-317. https://doi.org/10.13189/ujer.2019.070201

Köylüoğlu, A. S., Bedük, A., Duman, L., \& Büyükbayraktar, H. H. (2015). Analyzing the relation between teachers' organizational silence perception and whistle blowing perception. Procedia - Social and Behavioral Sciences, 207, 536-545. https://doi.org/10.1016/j.sbspro.2015.10.124

Le, P. D., Teo, H. X., Pang, A., Li, Y., \& Goh, C. Q. (2019). When is silence golden? The use of strategic silence in crisis communication. Corporate Communications, 24(1), 162-178. https://doi.org/10.1108/CCIJ-10-2018-0108

Milliken, F. J., Morrison, E. W., \& Hewlin, P. F. (2003). An exploratory study of employee silence: Issues that employees don't communicate upward and why. Journal of Management Studies, 40(6), 1453-1476. https://doi.org/10.1111/1467-6486.00387

Mokhtari, H. (2016). What makes academic librarians organizationally silent? International Federation of Library Associations and Institutions, 42(3), 220-226. https://doi.org/10.1177/0340035216662663

Morrison, E. W., \& Milliken, F. J. (2000). Organizational silence: A barrier to change and development in a pluralistic world. Academy of Management Review, 25(4), 706-25. https://doi.org/10.5465/amr.2000.3707697

Nafei, W. A. (2016). Organizational silence: Its destroying role of organizational citizenship behavior. International Business Research, 9(5), 57-75. https://doi.org/10.5539/ibr.v9n5p57

Pinder, C. C., \& Harlos, K. P. (2001). Employee silence: Quiescence and acquiescence as responses to perceived injustice. In Research in Personnel and Human Resources Management (Vol. 20, pp. 331-369). Emerald Group Publishing Limited. https://doi.org/10.1016/S0742-7301(01)20007-3

Qazelvand, R., \& Shahtalebi, B. (2016). Survey of the relationship between Organizational silence and organizational commitment of Junior secondary and senior teachers of Azna City. Review of European Studies, 8(2), 105. https://doi.org/10.5539/res.v8n2p105

Raosoft. (2004). Sample size calculator. http://www.raosoft.com/samplesize.html 
Shahjehan, A., \& Yasir, M. (2016). Surface and deep conceptualizations of silence and voice paradoxes: An empirical analysis of women behavior at workplace. Cogent Business and Management, 3, 1221560. https://doi.org/10.1080/23311975.2016.1221560

Tangirala, S., \& Ramanujam, R. (2008). Employee silence on critical work issues: The cross level effects of procedural justice climate. Personnel Psychology, 61(1), 37-68. https://doi.org/10.1111/j.1744-6570.2008.00105.x

Wynen, J., Kleizen, B., Verhoest, K., Lægreid, P., \& Rolland, V. (2019). Just keep silent... Defensive silence as a reaction to successive structural reforms. Public Management Review, 22(4), 1-29. https://doi.org/10.1080/14719037.2019.1588358

Yalçın, B., \& Baykal, Ü. (2019). Development and psychometric testing of the Organizational Silence Behavior Scale for healthcare professionals. Nursing and Health Sciences, 21(4), 454-460. https://doi.org/10.1111/nhs.12619

Zhang Y., Xu, S., Zhang L., \& Liu, S. (2018). How family support influences work cynicism and employee silence: The moderating Role of Gender, 60(3), 249-261. https://doi.org/10.1177/1938965518788526

\title{
THE EXPRESSION OF ORGANIZATIONAL SILENCE FACTORS IN EDUCATIONAL INSTITUTIONS
}

\section{Greta BRUSOKAITĖ, Laima JESEVIČIŪTĖ-UFARTIENE்}

\begin{abstract}
Improving an organization and adapting to changing conditions in a competitive environment depends on the ability of employees to freely express their knowledge, desires, suggestions and initiatives about change and development within the organization. If employees do not have these opportunities or feel uncomfortable in their work environment, organizational silence can occur. This phenomenon has negative consequences for the individual and for the quality of the services which organizations provide. The quality of services is particularly important for the education sector, because these services are provided to every citizen of the country. Therefore, the purpose of this article is to investigate the occurrence of factors of organizational silence in educational institutions based on scientific sources, their analysis and empirical research. The survey was conducted in three educational institutions (X1, X2, X3 - institutions wished to remain confidential). Multi-criteria TOPSIS method was used for data analysis of empirical research. There was found that the factors of organizational silence are different in the three educational institutions. For this reason, we can assume that much wider research is needed for each educational institution to investigate the causes and effects of organizational silence.
\end{abstract}

Keywords: organizational silence, organizational culture, communication, educational institutions, factor expression. 